\title{
PENGUATAN NILAI-NILAI KEBANGSAAN \\ DALAM RANGKA MENCEGAH RADIKALISASI PADA ORGANISASI SISWA INTRA SEKOLAH (OSIS) DI SEKOLAH MENENGAH ATAS KABUPATEN BOYOLALI
}

\author{
Kundharu Saddhono dan Sri Hastuti \\ Universitas Sebelas maret \\ Email: kundharu_s@staff.uns.ac.id
}

\begin{abstract}
Abstrak
Sekolah saat ini sangat rentan disusupi oleh paham dan gerakan radikalisme. Hal ini dikarenakan belum ada satu pun kebijakan spesifik untuk melindungi atau memproteksi sekolah dari penetrasi pahan dan gerakan radikalisme. Dalam rangka mewujudkan perlindungan terhadap siswa di sekolah terhadap paham radikalisme maka pendidikan nilai-nilai kebangsaan untuk siswa sekolah diperlukan sebagai bentuk kepedulian dari setiap pihak, baik pemerintah, masyarakat, keluarga terutama sekolah. Pendidikan nilai kebangsaan untuk siswa akan terbentuk jika semua pihak memilki kesadaran akan pentingnya pendidikan nilai kebangsaan dimulai semenjak dini. Guru adalah posisi paling strategis untuk membentuk karakter siswa. Pendidikan nilai kebangsaan pada siswa sekolah inilah yang menjadi dasar pembentukan awal karena meluruskan sebatang ranting jauh lebih mudah daripada meluruskan sebatang pohon, maka dari itu pendidikan nilai kebangsaan yang paling efektif adalah pendidikan pada siswa sekolah. Pengembangan nilai-nilai budaya dan karakter bangsa siswa sekolah harus dilakukan dengan tepat. Jika hal ini tidak bisa tercapai, pesan moral yang akan disampaikan orang tua dan pendidik kepada siswa menjadi terhambat. Pengembangan nilai moral untuk siswa sekolah bisa dilakukan di dalam tiga tri pusat pendidikan yang ada. Yaitu, keluarga, sekolah, dan masyarakat. Dalam pengembangan nilai moral untuk siswa sekolah perlu dilakukan dengan sangat hati-hati. Hal ini dikarenakan siswa sekolah adalah anak yang sedang dalam tahap perkembangan praoperasional konkret. Maka dari itu, tim pengabdi melaksanakan kegiatan pengabdian berkaitan dengan penanaman nilai-nilai kebangsaan terhadap siswa sekolah, bertujuan untuk mengatasi perpecah-belahan masyarakat Indonesia ini dan mencegah radikalisme siswa, mengingat banyaknya kelompok separatis lahir di Indonesia ini maka salah satu cara untuk memeutuskan rantai gejolak yang bertujuan menghancurkan Negara Kesatuan Republik Indonesia (NKRI) ini dengan menanamkan nilai-nilai wawasan kebangsaan terhadap siswa sekolah.
\end{abstract}

Kata Kunci: Nilai Kebangsaan, SMA, radikalisme, siswa, OSIS

\section{PENDAHULUAN}

Sekolah saat ini sangat rentan disusupi oleh paham dan gerakan radikalisme. Hal ini dikarenakan belum ada satu pun kebijakan spesifik untuk melindungi atau memproteksi sekolah dari penetrasi pahan dan gerakan radikalisme. Dalam rangka mewujudkan perlindungan terhadap siswa di sekolah terhadap paham radikalisme maka pendidikan nilai-nilai kebangsaan untuk siswa sekolah diperlukan sebagai bentuk 
kepedulian dari setiap pihak, baik pemerintah, masyarakat, keluarga terutama sekolah. Pendidikan nilai kebangsaan untuk siswa akan terbentuk jika semua pihak memilki kesadaran akan pentingnya pendidikan nilai kebangsaan dimulai semenjak dini. Guru adalah posisi paling strategis untuk membentuk karakter siswa. Pendidikan nilai kebangsaan pada siswa sekolah inilah yang menjadi dasar pembentukan awal karena meluruskan sebatang ranting jauh lebih mudah daripada meluruskan sebatang pohon, maka dari itu pendidikan nilai kebangsaan yang paling efektif adalah pendidikan pada siswa sekolah.

Pengembangan nilai-nilai budaya dan karakter bangsa siswa sekolah harus dilakukan dengan tepat. Jika hal ini tidak bisa tercapai, pesan moral yang akan disampaikan orang tua dan pendidik kepada siswa menjadi terhambat. Pengembangan nilai moral untuk siswa sekolah bisa dilakukan di dalam tiga tri pusat pendidikan yang ada. Yaitu, keluarga, sekolah, dan masyarakat. Dalam pengembangan nilai moral untuk siswa sekolah perlu dilakukan dengan sangat hati-hati. Hal ini dikarenakan siswa sekolah adalah anak yang sedang dalam tahap perkembangan praoperasional konkret seperti yang dikemukakan oleh Piaget. Sedangkan nilai-nilai moral merupakan konsep-konsep yang abstrak. Sehingga dalam hal ini siswa belum bisa dengan serta-merta menerima apa yang diajarkan guru atau orang tua yang sifatnya abstrak secara cepat. Untuk itulah orang tua dan pendidik harus pandai-pandai dalam memilih dan menentukan metode yang akan digunakan untuk menanamkan nilai moral kepada anak agar pesan moral yang ingin disampaikan guru dapat benar-benar sampai dan dipahami oleh siswa untuk bekal kehidupannya nanti.

Bangsa merupakan suatu komunitas “terbayang”. Para anggota bangsa terkecil sekalipun tidak tahu dan tidak kenal dengan sebagaian besar anggota lain, tidak akan bertatap muka dengan mereka itu, bahkan mungkin pula tidak mengenal tentang mereka. Hal terpenting dalam tetap berdirinya sebuah bangsa adalah adanya perasaan kebersamaan dan persaudaraan sebagai anggota komunitas bangsa tersebut. Hal tersebut muncul adalah akibat kuatnya akar-akar nasionalisme (Mahfud, 2014: 7).

Negara kesatuan Republik Indonesia (NKRI) merupakan "harga mati" bagi tetap berdirinya bangsa. Pancasila dijadikan sebagai falsafah perilaku kehidupan bersama, yang selain mendasari wacana kehidupan seseorang juga memiliki kontekstual penerapannya dalam kehidupan berpolitik, ekonomi, sosial-budaya, pendidikan, dan tahap kehidupan 
global dalam membangun dunia. UUD 45 sebagai pedoman tatanan kehidupan berbangsa, dan Bhineka Tunggal Ika sebagai acuan dalam menyikapi kehidupan bersama dalam situasi keadaan bangsa yang bersifat multikultur. Indonesia juga memiliki kedaulatan untuk menjalankan kemerdekaan memiliki budaya (Saddhono, 2014; Raharjo, 2003: 185)

Menurut Samuel Hutingthon pernah berkomentar pada akhir abad ke- 20, bahwa Indonesia adalah negara yang mempunyai potensi paling besar untuk hancur, setelah Yugoslavia dan Uni Soviet akhir abad ke-20 ini. Demikian juga Cliffrod Gertz, antropolog yang Indonesianis ini pernah mengatakan; kalau bangsa Indonesia tidak pandai-pandai mengatur keanekaragaman etnik, budaya, dan solidaritas etnik, maka Indonesia akan pecah menjadi negara-negara kecil (Sumarsono, 2001)

Maka dari itu, tim pengabdi mengajukan kegiatan pengabdian berkaitan dengan penanaman nilai-nilai kebangsaan terhadap siswa sekolah, bertujuan untuk mengatasi perpecah-belahan masyarakat Indonesia ini dan mencegah radikalisme siswa, mengingat banyaknya kelompok separatis lahir di Indonesia ini maka salah satu cara untuk memeutuskan rantai gejolak yang bertujuan menghancurkan Negara Kesatuan Republik Indonesia (NKRI) ini dengan menanamkan nilai-nilaiwawasan kebangsaan terhadap siswa sekolah.

SMA Bhinneka Karya 3 dan SMK Bhinneka Karya 5 adalah bagian dari SMA di Kabupaten Boyolali dan merupakan lembaga pendidikan tingkat menengah yang berupaya menanamkan nilai-nilai kebangsaan kepada siswa-siswinya. Sekolah ini mempunyai keunikan tersendiri atau ciri khas yang membedakan dengan sekolah-sekolah lain yang sederajat. Ciri khas tersebut yang kemudian menjadi faktor pendukung dalam pelaksanaan penanaman nilai-nilai kebangsaan pada siswa. Keunikan atau ciri khasnya yaitu: pertama, mengedepankan pendidikan budi luhur, yaitu sebagai mana yang ditegaskan dalam visi misinya. Kedua, berupa pendidikan budaya-budaya lokal (Jawa) dolanan anak, dan anak-anak juga dilatih mewarnai lukisan batik yang sudah disediakan oleh sekolah (Observasi Tim, 2018). Kemudian yang, ketiga, perlakuan guru terhadap siswa seperti orang tua terhadap anaknya, dan sikap siswa terhadap gurunya seperti anak kepada orang tuanya. Kelima, diberikan pendidikan keistimewaan, salah satunya pendidikan keistimewaan itu, mengenalkan budaya, mengunjungi tepat bersejarah seperti, Candi Borobudur, museum, kraton dan lain-lainnya (wawancara Guru) 
Berdasarkan gambaran tersebut, maka penulis tertarik untuk meneliti lebih jauh dalam hal penanaman nilai-nilai kebangsaan terhadap Siswa-siswa SMA dan SMK Bhinneka Karya Kabupaten Boyolali. Dengan ini diharapkan informasi yang diperoleh dari hasil pengabdian ini bisa menjadi sumbangsih berarti dan penting bagi lembaga pendidikan, di dalam penanaman nilai-nilai kebangsaan terhadap siswa sekolah.

\section{METODE}

Tempat pelaksanaan pengabdian ini berada di Kabupaten Boyolali, Provinsi Jawa Tengah. Dalam proposal ini dilampirkan pernyataan 2 mitra, yaitu SMA Bhinneka Karya 3 dan SMK Bhinneka Karya 5. Waktu pelaksanaan program pengabdian ini direncanakan 8 bulan dan detail kegiatan terlampir pada jadwal pelaksanaan program pengabdian.

\section{HASIL DAN PEMBAHASAN}

Pelaksanaan pengabdian ini direncanakan dalam 3 kegiatan utama yang masingmasing mempunyai bentuk kegiatan yang berbeda. Kegiatan tersebut adalah Tahap Persiapan; Tahap persiapan ini berkaitan dengan hal yang perlu dipersiapkan dalam rangka pelaksanaan pengabdian ini. Persiapan awal yang dilakukan adalah survei awal ke tempat atau lokasi pengabdian untuk mendapatkan data awal. Setelah mendapatkan data awal baru menyusun rencana kegiatan pengabdian sesuai dengan kondisi permasalahan yang dihadapi guru-guru dan siswa dalam implementasi nilai-nilai kebangsaan di SMA Kabupaten Boyolali. Pada tahap ini juga dilakukan prakondisi dalam pelaksanaan implementasi nilai-nilai kebangsaan di lingkungan sekolah Kabupaten Boyolali.

Tahap Pelaksaaan; Tahap pelaksanaan adalah inti dari pengadian ini yang akan dilakukan di sekolah. Hasil pengumpulan data di sekolah kemudian dianalisis dan diklasifikasikan hal-hal yang dapat dipadukan bahan untuk mengadakan implementasi nilai-nilai kebangsaan bagi guru-guru dan siswa-siswa SMA di Kabupaten Boyolali. Berdasarkan hasil analisis tersebut, dibuatlah sebuah pelatihan atau pendampingan untuk guru dan siswa dalam implementasi dan pelaksanaan nilai-nilai kebangsaan. Diharapkan dengan pelatihan atau pendampingan ini dapat meningkatkan kesadaran bersama akan nasionalisme dan mencegah paham radikalisme, terutama bagi siswa- 
siswa SMA di Kabupaten Boyolali.

Tahap Evaluasi; Tahap evaluasi adalah tahap akhir dari pengabdian ini yang akan dilakukan oleh tim dosen dengan tim pengabdian mengenai evaluasi terhadap apa yang telah dilakukan para guru dan siswa sebelum dan sesudah pelaksanaan pelatihan dan pendampingan berkaitan implementasi nilai-nilai kebangsaan di lingkungan sekolah dalam mencegah paham radikalisme pada siswa-siswa SMA Kabupaten Boyolali.

Pelaksanaan program pengadian ini direncanakan berlangsung 8 bulan yang dimulai pada awal tahun 2018. Pelaksanaan tersebut diawali dengan perencanaan, pelaksanaan, dan diakhiri dengan evaluasi.

Pada setiap kegiatan pengabdian yang dilakukan oleh Riset Group harus terarah berkaitan dengan target dan sasarannya. Adapun target luaran program pengabdian ini dapat dipilah menjadi dua hal, yaitu produk kegiatan pengabdian dan hasil program pengabdian. Penjelasan dari luaran tersebut adalah dalam pelaksanaan pengabdian ini, tim pengabdi mempunyai indikator tercapainya kegiatan. Capaian produk program pengabdian ini dapat dipaparkan dalam penjelasan yaitu tersosialisasikan program nilai-nilai kebangsaan yang merupakan implementasi dari 4 konsensus nasional di Kabupaten Boyolali. Dengan adanya pengabdian ini diharapkan siswa-siswa SMA di Kabupaten Boyolali semakin memahami nilai-nilai yang terkandung dalam 4 konsensus nasional, yaitu Pancasila, UUD 1945, Bhineka Tunggal Ika, dan NKRI. Siswa dapat mengimplementasikan hasil pengadian ini sehingga tercipta suasana yang kondusif dan dapat mencegah paham radikalisme siswasiswa SMA di Kabupaten Boyolali. Guru dapat membantu dalam penerapan dan implementasi nilai-nilai kebangsaan tersebut melalui kegiatan pembelajaran dan memberi contoh kepada siswa-siswa di sekolah dan di masyarakat. Terbitnya sebuah peraturan di sekolah yang tertulis maupun tidak tertulis untuk dapat melaksanakan nilai-nilai kebangsaan tersebut di lingkungan sekolah, misalnya dengan menyanyikan lagu-lagu nasional saat akan memulai proses pembelajaran di kelas dan kegiatan lainnya yang menguatkan nilai-nilai kebangsaan bagi diri guru dan siswa.

Produk Kegiatan Pengabdian yaitu buku pedoman atau panduan mengenai penerapan dan implemetasi nilai-nilai kebangsaan di lingkungan sekolah bagi siswa dan guru, khususnya tingkat SMA di Kabupaten Boyolali. Terbitnya dokumentasi dalam 
pelaksanaan nilai-nilai kebangsaan bagi guru dan siswa SMA di Kabupaten Boyolali dan dikelola oleh sekolah dengan bimbingan tim pengabdian dari Universitas Sebelas Maret. Modul atau bahan ajar mengenai implementasi dan pelaksanaan nilai-nilai kebangsaan bagi guru dan siswa SMA di Kabupaten Boyolali. Artikel jurnal pengabdian mengenai kegiatan implementasi dan pelaksanaan nilai-nilai kebangsaan dalam mencegah paham radikalisme pada Sekolah Menengah Atas (SMA) di Kabupaten Boyolali, Jawa Tengah.

Hasil Program Pengabdian ini dapat dibagi dalam 2 bagian, yaitu jangka pendek dan jangka panjang. Secara garus besar hasil program pengabdian ini dapat dijelaskan yaitu dalam jangka pendek, para siswa dan guru di Kabupaten Boyolali, khususnya tingkat SMA dapat meningkatkan kemampuannya dalam implementasi nilai-nilai kebangsaan yang dapat menangkal paham radikalisme di sekaolah terutama untuk siswa. Para guru dan siswa termotivasi untuk selalu melaksanakan nilai-nilai kebangsaan dalam ramgka menjaga kondisifitas lingkungan sekolah. Dalam jangka panjang dapat terus dilakukan dalam rangka memberikan pendidikan nilai-nilai kebangsaan yang berkelanjutan yang ditujukan untuk guru dan siswa di tingkat Sekolah Menengah Atas (SMA), khususnya di Kabupaten Boyolali, Jawa Tengah. Terlebih dengan adanya sistem pendidikan nilainilai kebangsaan yang terprogram oleh para guru dan siswa sehingga dengan adanya penanaman karakter yang kuat diharapkan dapat terus dijadikan lingkungan sekolah sebagai benteng utama Pancasila yang dilaksanakan di Kabupaten Boyolali untuk menghasilkan genersi muda yang toleran dan anti radikalisme.

\section{KESIMPULAN}

Keberhasilan pengabdian ini tentunya berdampak pada Universitas Sebelas Maret sebagai penyelenggara. Kegiatan ini mencerminkan bahwa salah satu tanggung jawab perguruan tinggi terhadap masyarakat tewujud dalam kegiatan pengabdian ini, khususnya yang berkaitan penerapan nilai-nilai kebangsaan di lingkungan pendidikan. Kegiatan ini juga mencerminkan bahwa kebutuhan penguatan nilai-nilai kebangsaan sangat diperlukan di lingkungan sekolah sebagai sarana pencegahan tindakan radikalisme di kalangan siswa. Hal ini menjadi salah satu tanggung jawab akademik bagi tim dosen atau pengabdian sebagai bentuk pengabdian ilmu yang telah mendapatkan ilmunya di perguruan tinggi. 


\section{DAFTAR PUSTAKA}

Bintarto, R.. 1980. Gotong Royong: Suatau karakterstik bangsa Indonesia. Surabaya: PT Bina Ilmu

Kaelan. 1987. Pancasila Yuridis Kenegaraan. Yogyakarta: Liberty

Isran Noor. 2012. Politik Otonomi Daerah untuk Penguatan NKRI. Jakarta: Penerbit APKASI

Mahfud MD. 2014. Demokrasi dan Konstitusi di Indonesia. Jakarta: Rineka Cipta

Raharjo Satjipto. 2013. Sisi-sisi Lain dari Hukum di Indonesia. Jakarta: Penerbit Kompas

Saddhono, Kundharu. 2014. Pembelajaran Keterampilan Berbahasa Indonesia: Teori dan Praktik. Yogyakartaa; Graha Ilmu.

Sumarsono. 2001.Pendidikan Kewarganegaraan. Jakarta: PT Gramedia Pustaka Utama

Tim. 2017. Nilai-nilai Krebangsaan yang Bersumber dari Pancasila. Jakarta: Lemhannas RI

Tim. 2017. Nilai-nilai Krebangsaan yang Bersumber dari UUD NRI Tahun 1945. Jakarta:Lemhannas RI

Tim. 2017. Nilai-nilai Krebangsaan yang Bersumber dari Bhinneka Tunggal Ika (BTI). Jakarta: Lemhannas RI

Tim. 2017. Nilai-nilai Krebangsaan yang Bersumber dari Negara Kresatuan Republik Indonesia (NKRI). Jakarta: Lemhannas RI 